\title{
COMMENTS
}

\section{Welfare for Strikers: ITT v. Minter}

During the past decade, striking workers have received increasing amounts of public welfare benefits. ${ }^{1}$ Although strikers have long benefited from General Assistance ${ }^{2}$ and unemployment compensation ${ }^{3}$ programs in some states, the creation of two new federal programs, food stamps ${ }^{4}$ and Aid to Families with Dependent Children of Unemployed Fathers (AFDC-U), ${ }^{5}$ has substantially increased the amount of aid available. Moreover, eligibility requirements for nearly all state and federal welfare programs have been liberalized, ${ }^{6}$ and strikers have grown increasingly aggressive in availing themselves of these benefits. ${ }^{7}$

1 Gannon, Strikers on Welfare, Wall Street Journal, July 14, 1971, at 1, col. 6.

2 Striking workers in Illinois received public aid as early as 1904. City of Spring Valley v. County Bureau, 115 III. App. 545 (1904) (striker cannot be denied aid under local welfare regulation).

General Assistance is a term of broad application and will be used herein to describe state-financed and -controlled programs of aid to able-bodied, working-age males. This term is meant to include state programs that provide aid in separate categories as well as those that aid indigents generally.

3 Beginning in 1936 a few states granted unemployment compensation benefits to strikers if the strike lasted longer than a specified period, usually seven to ten weeks. Shadur, Unemployment Benefits and the "Labor Dispute" Disqualification, 17 U. CHr. L. REv. 294, 317 n.100 (1950). Several states presently grant benefits to workers unemployed due to a lockout. Note, Effect of Participation in a Labor Dispute upon Continuation of Unemployment Benefits, 52 CoRNELL L.Q. 738, 741 (1967). But only two states continue to grant benefits to strikers. N.Y. LABOR LAW \& 592.I (McKinney 1965); R.I. Gen. LAWS ANN. § 28-44-16 (1966). In addition, the Federal Railroad Unemployment Insurance Act permits railroad workers to receive unemployment insurance during a strike. 45 U.S.C. § 351, 354(a-2)(iii) (1970).

4 The program allows indigents to buy government certificates exchangeable for food at a cost lower than their face value. The program was created in 1964. Act of Aug 31, 1964, Pub. L. No. 88-525, §§ 2-16, 78 Stat. 703 (codified at 7 U.S.C. §§ 2011-15 (1970)).

5 The program was created in 1961. Act of May 8, 1961, Pub. L. No. 87-31, § 407, 75 Stat. 75, amending 42 U.S.C. $\$ \S 601-06$ (1958) (codified at 42 U.S.C. $\S 607$ (1970)).

6 For example, the amount one may earn while receiving AFDG-U benefits was increased in 1967. Social Security Amendments of 1967, Act of Jan. 2, 1968, Pub. L. No. 90-248, § 202, 81 Stat. 821, amending 42 U.S.C. $\S 602$ (1964) (codified at 42 U.S.C. $\S 602$ (1970)). The development of present welfare eligibility requirements is described in President's Comm'n on Income Maintenance Programs, Poverty Amid Plenty: The American Paradox 121-22 (1969) [hereinafter cited as Heineman Report].

7 Gannon, supra note 1, Both union rank and file and their leaders seem to have overcome personal and ideological inhibitions about applying for welfare. One authority who 
The resulting upsurge in the number of strikers receiving public aid ${ }^{8}$ has stimulated criticism of the programs ${ }^{9}$ and attempts to modify existing legislation. ${ }^{10}$ Thus far, however, there has been no study of the legal implications of these developments for the collective bargaining process. ${ }^{11}$

has directed extensive field work in this area suggests that this attitudinal change is a key factor in the upsurge of striker participation in welfare programs. Affidavit of Herbert $P$. Northrup, Director, Industrial Research Unit, Wharton School of Finance and Commerce, University of Pennsylvania at 12, in support of Brief for American Chamber of Commerce as Amicus Curiae, Francis v. Davidson, Civil Action No. 71-853K (D. Md., filed Aug. 9, 1971).

8 The potential for widespread community support of a strike was demonstrated in the 1959 United Steelworkers strike. Forty-five million dollars was raised from private and public sources to aid the half-million workers during the four months work was halted. U.S. News \& WORLD REPORT, Oct. 3, 1960, at 101. It was not until the late 1960s, however, a period of rising inflation, that the full impact of changes in welfare legislation and union tactics became apparent as strikes across the nation brought record amounts of welfare support. See text at notes 133-34, 149-51 infra.

This development was not limited to welfare funds. New York's unemployment compen. sation fund experienced a record depletion during 1970 due to claims by strikers. N.Y. State Dep't of Labor, The Industrial Controversy Provision of the New York State UNEMPLOYMENT INSURANCE LAW 19 (Working Paper No. 6, 1971). Unusual strikes also occurred in the railroad industry, where workers are protected by the Railroad Unemployment Insurance Act. Transportation Ass'N OF AMERICA, Government Aid to Strikers, AN INEquitable and Inflationary Practice 6 (1969). Apparently, unemployment compensation payments to striking trainmen have increased since 1960 . See F. Briggs, A Study of Strike Subsidies 68 (1965) (unpublished Ph.D. thesis, Michigan State University).

o E.g., Editorial, Wall Street Journal, July 19, 1971, at 7, col. 1. Representative views are quoted in Gannon, supra note 1.

10 Several amendments have been offered in both the House and Senate to exclude strikers from the food stamp program. S. 781, S. 1773, 92d Cong., Ist Sess. (1971); H.R. 6572, H.R. 7535, 92d Cong., 1st Sess. (1971). Similar amendments have been defeated in the past. See, e.g., 116 CoNG. REc. H12541 (1970).

The Nixon Administration unsuccessfully recommended legislation that would have prohibited states from granting unemployment compensation to strikers. H.R. 12625, 91st Cong., Ist Sess. $\S 121(a)(10)$ (1969). The recommendation was deleted by the House Ways and Means Committee after hearings indicated that management and labor in the affected states preferred to resolve the issue at the state level. H.R. REP. No. 91-612, 91st Cong., lst Sess 18 (1969). The Administration has introduced similar legislation that would eliminate unemployment insurance grants to striking railroad workers. S. 560, 92d Cong., Ist Sess. (1971).

On the other hand, the Administration and others have introduced welfare reform. measures that would guarantee a minimum income to all persons, presumably including strikers. H.R. 1, 92d Cong., l'st Sess. § 448 (1971); H.R. 1, 92d Cong., 1st Sess § 2111(c) (1971); H.R. ReP. No. 92-231, 92d Cong., Ist Sess. (1971). See text at notes 182-92 infra. But an amendment has been introduced that would deny strikers welfare benefits. H.R. 6004, 92d Cong., Ist Sess. (1971).

11 A major study of the economic impact of welfare on collective bargaining is currently being completed at the Industrial Research Unit of the Wharton School of Finance, University of Pennsylvania. The author is grateful for permission to use excerpts 
The National Labor Relations Act $^{\mathbf{1 2}}$ relies on the economic pain caused by a work stoppage as the primary inducement to the voluntary settlement of labor-management disputes. ${ }^{13}$ The aim of welfare legislation, on the other hand, is to alleviate economic hardship. Accordingly, the purposes of the NLRA and of welfare legislation conflict when a worker applies for welfare benefits to cushion the financial impact of a strike.

Conflict between the NLRA and the food stamp and unemployment compensation programs was recently resolved by federal legislative and administrative action expressly permitting strikers to receive benefits under these programs. ${ }^{14}$ But the legal relationship between the NLRA and the AFDG-U and General Assistance programs remains unclear. The language of both the welfare regulations and the NLRA are silent on the issue of whether a striker may receive welfare. And judicial interpretation and reconciliation of the relevant statutes is complicated by the broad policy issues involved and the lack of information concerning the impact of welfare grants on collective bargaining. These difficulties recently emerged in ITT $v$. Minter, ${ }^{15}$ in which a federal court ruled for the first time that strikers may receive AFDC-U and General Assistance benefits.

\section{ITT v. Minter}

The facts of the case illustrate the problem that welfare benefits pose for the collective bargaining process. On August 24, 1970, after several months of unsuccessful negotiations, the Lynn, Massachusetts

from the forthcoming work. A. Thieblot \& R. Cowin, Welfare and Strukes: The Use of PUblic Funds to SUpPort Strikes (1972).

A discussion of the legal conflict between the federal labor policy and the work requirement in unemployment compensation is found in Mandelker, Refusals to Work and Union Objectives in the Administration of Taft-Hartley and Unemployment Compensation, 44 Cornell L.Q. 477 (1959). See also Note, Strikers Right to Public Assistance, 16 DePaul. L. Rev. 517 (1967).

1229 U.S.C. $\S 141$ et seq. (1970).

13 N. Chamberlain, Labor 97-111 (1958).

14 In the case of food stamps the Department of Agriculture, after Congress had defeated a recent attempt to eliminate strikers from the progxam, see note 10 . supra, published regulations explicitly guaranteeing strikers eligibility. for benefits. 36 Fed. Reg. 14108 (1971). In the case of unemployment compensation Congress recently refused to prohibit states from granting benefits to strikers. See authorities cited note 10 supra.

15435 F.2d 989 (Ist Cir. 1970), cert. denied, 402 U.S. 933 (1971). Two state cases have also upheld welfare grants to strikers without discussing the question of conflict with the federal labor policy. Strat-O-Seal Mfg. Co. v. Scott, 72 Ill. App. 2d 480, 218 N.E.2d 227 (1966); Lascaris v. Wyman, 61 Misc. 2d 212, 305 N.Y.S.2d 212 (Sup. Ct. 1969). 
plant of the ITT Lamp Division of the International Telephone and Telegraph Company was struck by 666 of its 800 production employees, who were members of Truck Drivers, Chauffers, and Helpers Local No. 42. Immediately following the walkout, twenty-five percent of the strikers applied for and received welfare benefits under Massachusetts programs of General Relief ${ }^{16}$ and AFDG-U Emergency Relief. ${ }^{17}$ Strikers eligible for AFDG-U benefits received up to $\$ 349$ per month and those eligible for General Relief benefits received up to $\$ 270$ per month during the nine-week strike. ${ }^{18}$

On September 21 the employer sought preliminary and permanent injunctive relief in a federal district court against the commissioner of the state welfare department to prevent further payments to strikers. After a hearing the district judge denied relief ${ }^{19}$ on the ground that the employer had failed to demonstrate irreparable harm because it could not prove that welfare benefits would prolong the strike.

On appeal ${ }^{20}$ the employer raised two objections. First, it argued that the states were preempted by the NLRA from granting welfare benefits to strikers because such grants altered the relative strengths of the

16 Mass. ANN. Laws ch. 117 (1968).

17 Id. ch. 118 (1968) (corresponding to 42 U.S.C. $\$ \S 601-07$ (1970)). Although the AFDGU program normally requires a thirty-day period of unemployment prior to eligibility, immediate assistance may be given at the state's option under the AFDG-U Emergency Relief Program. 42 U.S.C. § 602 (1970). Massachusetts does not participate in the food stamp program, and strikers are ineligible for unemployment compensation. MAss. ANN. LAwS ch. I5IA, \& 25 (1968).

18 The strike ended on October 27. Workers received strike benefits from their union of fifteen dollars per week for the first month and twenty-five dollars per week thereafter. As the strike progressed more workers qualified for welfare benefits, and by the end of the strike more than two hundred strikers had received public aid.

19 ITT v. Minter, 318 F. Supp. 364 (D. Mass. 1970), affd, 435 F.2d 989 (Ist Cir. 1970), cert. denied, 402 U.S. 933 (1971).

20 The district court announced its decision on September 30, and on October 2 the First Circuit denied the employer's request for a preliminary injunction pending appeal. Although the strike was settled on October 27, the appeal was not heard until December. The grant or denial of a preliminary restraining order preventing a state from making welfare payments is thus crucial, since by the time the losing party has appealed the strike may be settled on the other party's terms.

In Minter the district court confused the issue by citing Goldberg v. Kelly, 397 U.S. 254 (1970), for the proposition that "welfare recipients should not be denied the benefits of the welfare system until a determination after full hearing that they are not entitled to them." 318 F. Supp. at 366. Goldberg was limited to the question of administrative due process, holding that prior to the termination of welfare payments the administrative agency must provide the recipient with an opportunity for an evidentiary hearing. Despite its reliance on Goldberg, the district court ordered suspension of payments pending the evidentiary hearing prior to final decision. Payments were suspended between September 23, the date of the original hearing, and September 30 , the date when evidence was finally taken. 
parties to the negotiations and thus interfered with the federal labor policy of relying on economic pressure to resolve bargaining deadlocks. Second, it argued that the grants were contrary to the language and purpose of the federal and state welfare statutes because the strikers were disqualified under the terms of the statutes as persons who had "without good cause . . . refused a bona fide offer of employment."22

The court rejected the second argument, ruling that since the relevent welfare statutes were silent on the question of striker eligibility the state administrator had complete discretion to determine the question. In the case of AFDG-U the court found that Congress had expressly delegated this discretion to the states. ${ }^{22}$ Although admitting that the legislative history of AFDC-U suggests that the program was "not designed to aid those who do not seek employment," it held that strikers do not fit this description because they are required as a condition of receiving welfare to register for and accept alternate work. ${ }^{23}$ In the case of General Relief the court noted that when the state intended to exclude strikers from other state programs, such as unemployment compensation, it utilized express language to do so. ${ }^{24}$

The court also rejected the preemption argument despite the difficult issue it posed. In San Diego Building Trades Council v. Gar$m^{25}$ the Supreme Court had established the general framework for preemption in labor relations, ruling that "when an activity is arguably subject to $\S 7$ or $\S 8$ of the Act [protecting concerted activities and proscribing unfair labor practices] the States as well as the federal courts must defer to the exclusive competence of the National Labor Relations Board."28 The First Circuit declared Garmon inapplicable

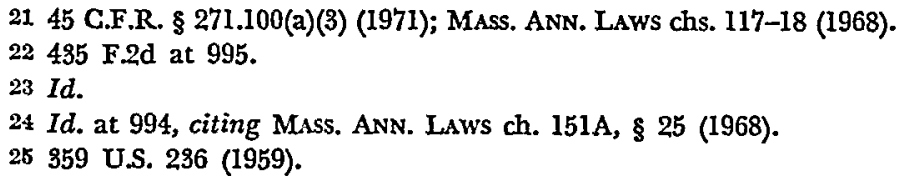

21. 45 C.F.R. § 271.100(a)(3) (1971); MAss. ANN. LAws chs. 117-18 (1968).

22485 F.2d at 995.

23 Id.

24 Id. at 994, citing Mass. ANN. LAws ch. 151A, \& 25 (1968).

25359 U.S. 236 (1959).

26 Id. at 245. Exceptions are allowed for activities of "merely peripheral concern" of the NLRA and for conduct that "touches interests so deeply rooted in local feeling and responsibility that, in absence of compelling congressional direction, we could not infer that Congress had deprived the states of power to act." Id. at 243-44.

Minter clearly involves a non-Garmon situation. Welfare grants to strikers do not restrict union members from engaging in concerted activities protected by section 7 of the NLRA. And such grants do not raise the issue of unfair labor practice under section 8 of the Act. Moreover, AFDC-U is partly a federal program and is therefore not subject to preemption under the supremacy clause. See text at notes 37-43, 49-54 infra.

Nevertheless, Garmon is relevant because it establishes the preemption doctrine in the Iabor field and indicates the general approach taken by the Supreme Court in its labor decisions. The sweep of federal preemption has been very broad, the Court having allowed few exceptions to Garmon under the "Iocal concern" and "peripheral concern" tests. See Currier, Defamation in Labor Disputes, 53. VA. L. REv. 1, 13 (1967). Moreover, 
to the present situation on the ground that state welfare grants to strikers do not involve a direct interference with federally protected or prohibited activities, but rather an indirect frustration of the federal policy of "free collective bargaining." 27 To resolve the conflict between welfare and labor laws, the court employed a balancing test in which the state interest in aiding indigent strikers was weighed against the federal interest in maintaining a uniform labor policy:

[T] he asserted conflict is not an invasion by the state into an area of conduct regulated by a national instrumentality but a tangential frustration of a national policy objective. ... [A] balancing process seems called for under the general approach to preemption followed by the Supreme Court . . . . ${ }^{28}$

The court added two prescriptions. First, the balancing process should not be limited to an ad hoc determination of the present dispute but should extend to an evaluation of the general problem of welfare for strikers. ${ }^{29}$ Second, the inquiry should be primarily empirical and should consider several factors: the number of states permitting strikers to receive welfare benefits, the number of strikers actually receiving benefits, a comparison between strike and welfare benefits, expert opinion evaluating the impact of welfare on strikers' resolve, and the extent to which welfare grants prolong the duration of strikes. ${ }^{30}$

The court was not, however, presented with evidence needed to make these empirical assessments. ${ }^{31}$ Nevertheless, it found that state welfare

it has narrowly construed the scope of federal legislation potentially conflicting with the NLRA. E.g., United States v. Hutcheson, 312 U.S. 219 (1941).

Recently, however, the court has indicated a willingness to reconsider Garmon. Justice White has suggested that preemption should extend only to activities that are "actually" rather than "arguably" protected under section 7. Longshoreman's Local 1416 v. Ariadne Shipping Co., 397 U.S. 195, 201 (1970) (White, J., concurring). See also Amalgamated Ass'n of Street Employees v. Lockridge, 91 S. Ct. 1909, 1929 (1971) (White, J., dissenting). The recent departure from the Court of Justices Black and Harlan leaves the future development of labor preemption much in doubt. See Note, Exclusive NLRB Jurisdiction Over Activity Arguably an Unfair Labor Practice, 85 HaRv. L. Rev. 334, 343 (1971).

27435 F.2d at 992.

$28 I d$.

$29 \mathrm{Id}$. at 993. Because the strike had ended prior to review by the First Circuit, the court had no choice but to consider the validity of future rather than past welfare grants to strikers. The court found support for its approach in Garmon's insistence that preemption decisions treat "classes of situations" rather than deal with particular disputes. $1 d$.

30 Id.

31 Briefs of Appellant and Appellee, passim. The employer had submitted empirical evidence to prove irreparable harm. Although this evidence was included in the district court record, the First Circuit chose to ignore the facts of the present dispute and instead considered the class of strike. cases generally. In a footnote, however, the court observed 
grants to strikers do not significantly frustrate the federal collective bargaining policy and thereby upheld the state interest in aiding indigent strikers over the federal interest in preventing state interference with the collective bargaining procedures established by the NLRA. ${ }^{32}$ The court declared further that even if such grants frustrated the federal labor policy they would be permissible because the state interest was substantial. ${ }^{33}$

This comment will examine (1) the Minter court's assertion that strikers are eligible for welfare grants ${ }^{34}$ and that such grants serve a substantial state interest, (2) the empirical impact of such grants on collective bargaining and the extent to which they frustrate the purpose of the NLRA, and (3) the proper role of the court in reconciling the objectives of welfare and labor legislation.

\section{The Welfare Programs}

Public welfare programs are many and varied, in both purposes and methods of administration. ${ }^{35}$ Welfare is administered at two levels. The states or their localities provide relief to all classes of indigents under General Assistance programs, and the federal government provides relief to particular classes of poor under categorical aid programs, such as AFDC-U, which are supervised primarily and funded partially by the states. ${ }^{36}$ Eligibility for both AFDG-U and General Assistance benefits is determined mainly on the basis of aggregate financial assets,

that the evidence was limited to the fact that twenty-five percent of ITT's striking employees had applied for benefits and stated that if the decision had to be made on the basis of this evidence alone, the employer would still not prevail because he would be unable to show by this evidence that the strike would have been prolonged. $435 \mathrm{~F} .2 \mathrm{~d}$ at 991 n.s.

32 In sum, wholly apart from the inadequacy of the evidence before the district court, we have substantial doubt that a significant frustration of bargaining policy is effected by the granting of welfare benefits to indigent strikers or that, even so, the state interest is so insubstantial compared to the federal interest that Congress must be supposed to have deprived the state of such power to serve that interest.

Id. at 994.

33 Id.

34 This comment will focus on the two welfare programs challenged in Minter. Other programs of public assistance may affect a striker's economic well-being, including (in addition to food stamps and unemployment compensation) veteran's benefits, public housing, and medical benefits. The effect of these programs is sporadic, and statistical information on striker participation is not available. It should be remembered, however, that the two programs to be discussed are not the exclusive means of public support of strikes.

35 For a full description of the various welfare programs, see HEINEMAN REPORT, supra note 6.

38 A person who is eligible for both AFDC-U and General Relief benefits normally receives state aid for a month or more and is then transferred to the federal program. 
weekly or monthly income, and compliance with the requirement that a welfare recipient not unjustifiably refuse employment or job training while receiving welfare benefits.

In upholding the grant of welfare benefits to strikers in Minter, the First Circuit made two critical assumptions. First, it construed AFDG-U legislation as giving the state administrator absolute discretion to interpret the work requirement and to grant or deny benefits to strikers. ${ }^{27}$ Second, it discussed AFDC-U and General Assistance grants as presenting the same issue of federal preemption of state activity under the NLRA. ${ }^{38}$ The AFDC-U work requirement is defined by federal regulations, however, and state interpretations of that requirement are subject to review by the Department of Health, Education and Welfare. ${ }^{3 p}$ Since AFDC- $U$ grants are federal in character they do not pose a preemption problem, but rather one of reconciling two federal statutes.

The state and federal welfare programs will consequently be analyzed separately. First, AFDG-U will be examined to determine whether grants to strikers are consistent with the language, legislative history, and policy of the program. Second, General Assistance will be examined to assess the Minter court's claim that there is a substantial state interest in granting welfare benefits to strikers.

\section{A. AFDG-U}

1. The Statutes. AFDC-U is a federal program of financial aid to dependents of unemployed, working-age, able-bodied males. ${ }^{40}$ The federal statute establishes a master program in which states may participate by passing their own statutes, which are then subject to approval by HEW.41 The federal statute and HEW regulations establish certain minimum requirements, but the state is given discretion in the administration of other aspects of the program. On the question of eligibility for benefits, the federal regulations explicitly delegate to the states the power to establish income and asset requirements. ${ }^{42}$ The definition of the work requirement, however, is expressly reserved to the Secretary of HEW. ${ }^{43}$

37435 F.2d at 994.

$38 \mathrm{Id}$.

39 See text at notes $49-54$ infra.

4042 U.S.C. $\$ 607$ (a) (1970). Roughly two-thirds of AFDG-U funds are supplied by the federal government. 42 U.S.C. \$ 603 (1970).

4142 U.S.C. $\$ \S 601,602$ (b) (1970).

42 See 42 U.S.C. $\$ \$ 601,602(a)(7), 603$ (1970); 45 C.F.R. $\$ 233.20(a)(2)$ (1971). The federal government places only minor limitations on the methods that states use to calculate income and need. 42 U.S.C. \$\$ 602(a)(8)(A)-(B), (D) (1970); 45 C.F.R. \$§ 233.20(a)(3)-(4), (6)-(7), (11) (1971).

43 The statute now reads: "The term 'dependent child" shall ... include a needy child 
Under the standard formulated by HEW, aid may be granted on the condition that the parent "has not without good cause, within the 30 day period prior to the receipt of aid, refused a bona fide offer of employment." HEW has listed few factors to be considered in making this determination, referring only to the employee's physical abilities and to "questions of working conditions, such as risks to health, safety, or lack of workman's compensation protection."44 Neither the federal statute nor the HEW regulations refer to the labor dispute problem.

The terms "good cause" and "unemployment" are difficult to apply to the strike situation. Under the NLRA a striker engaged in protected concerted activities is "employed" 45 unless he takes another job or is replaced by his employer.46 And although an employee has "good cause" to strike in that such activity is statutorily protected, ${ }^{47}$ the term does not distinguish between legally sanctioned strikes and others, such as wildcat strikes or strikes that constitute unfair labor practices. Unlike welfare legislation explicitly dealing with the strike situation, HEW regulations do not specify whether a striker receiving welfare may with "good cause" refuse to accept substitute work that would jeopardize his union status or require him to work at the site of another strike or lockout. ${ }^{48}$

State AFDC-U statutes interpreting the federal work requirement must be approved by HEW.49 Yet HEW has never had the opportunity

... who has been deprived of parental support or care by reason of the unemployment (as determined in accordance with standards prescribed by the Secretary) of his father." 42 U.S.C. § 607(a) (1970).

44 The HEW regulation reads:

[Aid will be granted if the] father has not without good cause, within such 30 day period prior to the receipt of aid, refused a bona fide offer of employment or training for employment. . . Questions with respect to the following factors must be resolved:

(a) That there was a definite offer of employment at wages meeting any applicable minimum wage requirements. ...

(b) Any questions as to the father's inability to engage in such employment for physical reasons or because he has no way to get to or from the particular job; and

(c) Any questions of working conditions, such as risks to health, safety, or lack of workman's compensation protection.

45 C.F.R. § 233.100(a)(3)(ii) (1971).

4529 U.S.C. \$ 152(3) (1970).

46 NLRB v. MacKay Radio \& Tel. Co., 304 U.S. 333 (1938).

4729 U.S.C. $\$ 157$ (1970). The right to strike is not equivalent to a constitutional right, however. See Local 32, UAW v. Wisconsin Employment Relations Bd., 396 U.S. 245, 252-53 (1949).

48 Such provisions prevent the state from using a welfare recipient as a strikebreaker or from using welfare to reduce union membership. They are a standard limitation on the work requirements of other public aid programs. E.g., N.Y. LABOR LAW § 592.1 (McKinney 1966) (unemployment compensation); 7 C.F.R. $\$ 271.3(c)(4)(E)(3)$ (1971) (food stamps). Such a provision is included in several welfare reform measures currently before Congress. See note 189 infra.

4942 U.S.C. \& 602(a) (1970). 
to approve a standard more specific than its own because no state law specifically grants or denies benefits to strikers. ${ }^{50} \mathrm{HEW}$ may also review state administrative interpretations of state AFDC-U statutes, ${ }^{, 51}$ but it has not invalidated any of the divergent interpretations currently in existence. Of the twenty-five states participating in the AFDC-U program, eighteen state administrators grant aid to strikers ${ }^{52}$ and seven do not. ${ }^{53}$

State discretion to interpret the term "good cause" does not derive, as the Minter court declared, from an explicit delegation by Congress to the states. Rather, it derives from the reluctance of HEW to clarify its own work requirement. HEW's tolerance of conflicting state interpretations must be reviewed in terms of the history and purpose of the AFDC-U program and the 1967 amendments to it. ${ }^{54}$

2. Legislative History. When Congress created the AFDC-U program in $1961^{55}$ it did not anticipate the possibility that strikers would become eligible for it. The program was created for the limited purpose of remedying defects in the pre-1961 Aid to Families with Dependent Children (AFDC) program. Prior to 1961 eligibility for the AFDC program had been limited to female heads of single-parent households, 56 with the result that unemployed fathers of needy families were encouraged to abandon the home (actually or fictitiously) in order that

50 Information about many aspects of the administration of welfare to strikers is unobtainable except through interviews or written inquiries. Information as to the number of states granting benefits to strikers was received in response to written inquiries to local welfare offices. Data on file at The University of Chicago Law Review.

5145 C.F.R. § 201.3 (1971). The requirements for periodic review of state welfare administration prescribe no particular method, and HEW does not review many local practices. See HeINEMAN REPORT, supra note 6, at 111.

52 Cal. Welf. \& INST'NS CODE §§ 11200-507 (Deering 1966); Colo. REv. Stat. ANN. § 119-9-1(4)(b) (1963); DeL. CODE ANN. tit. 31, § 504(2) (1953); D.C. CoDE ANN. \$ 3-202 (a)(4) (1967); HawaII Rev. LAws §§ 346-55 (1968); IlL. Rev. STAT. ch. 23, § 4.1 (1969); Mass. GEN. Laws ANN. ch. 118 (1968); Mich. Stat. ANN. \& 16.422-14 (1968); Mont. Rev. CODE ANN. §§ 71-501 to -510 (1971); N.J. REv. STAT. § 44:10-1(c)(1) (1937); OHIO REv. CodE Ann. § 5107.03(A) (Page 1970); Okra. Stat. ANn. tit. 56, \& 164(d)(2) (1969); Pa. Stat. AnN. tit. 62 \$§ 201 et seq. (1967); UTAH Code ANN. § 55-15-23(c)(1) (1963); VT. STAT. ANN. tit. 33, § 2701(I)(C)(iii) (1967); WASH. Rev. Code § 74.12.010 (1963); W. VA. CoDE ANN. \& 9-1-2(C) (1966). One state also grants unemployment compensation to strikers. N.Y. Soc. WELFARE LAW ANN. art. 5, tit. 1, 131 (McKinney 1966).

53 Aruz. Rev. Stat. ANN. § 46-292 (1956); Kan. Stat. ANN. § 39-709(D) (1969); MD. ANn. CODE art. 88A, § 45(c) (1957); MinN. Stat. § 256.12(14) (1967); Mo. ANn. Stat. § 208.041 (1968); Neb. Rev. StAT. § 43-504.01 (1968); ORE. Rev. Stat. \$ 418.070 (1969).

54 Review of agency action must, however, be limited where the agency acts pursuant to an express delegation of power from Congress. K.C. Davis, AdMinistrative LAW Treatise $\S 5.05$ (1965).

55 Act of May 8, 1961, Pub. L. No. 87-31, § 407, 75 Stat. 75, amending 42 U.S.C. $\S \S 601-06$ (1958) (codified at 42 U.S.C. $\$ 607$ (1970)).

56 Act of Aug. 14, 1935, ch. 531, \$§ 401-06, 49 Stat. 627. 
their dependents could qualify for public aid. In 1961 supporters of welfare reform argued that this problem was especially widespread because many fathers unemployed due to the 1959-60 recession had exhausted unemployment compensation and were not sufficiently assisted by state General Assistance programs. ${ }^{57}$ When Congress responded by creating the AFDC-U program, the action was taken primarily to aid persons suffering from long-term unemployment caused by the recession.

To insure that aid would be granted only to the intended recipients, Congress included a requirement, to be administered by the states, that recipients register for work and not refuse, without "good cause," "bona fide" offers of employment in which they were "able to engage." 58 This language was designed to limit eligibility to persons "involuntarily" unemployed.59 The term "good cause" was introduced as a safeguard to prevent the states from imposing arbitrary or punitive work requirements on eligible recipients. ${ }^{60}$

67 After pointing out that in 65.4 percent of homes receiving AFDC benefits the father was absent (deserting, divorced, separated, or not married to the mother), HEW Sec. Abraham Ribicoff said:

We do feel that in days such as this, with such a large amount of unemployment, so many people having exhausted their unemployment insurance payments... there should be considered . ... in the case of a child who is in a home where the father is out of a job, giving that child the same eligibility for ADC as a child whose parent is outside of the home.

Hearings on H.R. 3854 \& 3865 Before the House Comm. on Ways \& Means, 87th Cong., Ist Sess. 94-95 (1961). See also 107 Conc. REc. 1677, 1679 (1961) (President's Special Message to Congress on Program for Economic Recovery and Growth).

58 Act of May 8, 1961, Pub. L. No. 87-31, § 407, 75 Stat. 75.

59 An author of the House Report and a sponsor of the bill explained:

What the legislation does is to add the new category which says that if the breadwinner is unable to work and if he is involuntarily unemployed and no work is available, we will treat that family in the same manner we treat the family when the breadwinner is dead, absent, or incapacitated.

I recognize, and I think the committee recognizes, that as we move into this category of involuntarily unemployed people, we do have an additional problem, namely, the determination of whether it is really involuntary unemployment. . . .

[A]dditions [were] made by the committee to assure that aid would go to children of the involuntarily unemployed ....

107 CoNG. REC. 3767 (I961) (remarks of Rep. John Byrnes).

The employer in Minter argued that a striker is ineligible for welfare benefits because he is voluntarily unemployed. Courts as well as legislatures employ the same argument in denying unemployment compensation to strikers. See Mandelker, supra note 11, at 488-91. The use by Congress of the term "involuntary" is significant only because it did not depart from common usage. As a basis for distinguishing between eligible and ineligible unemployed, however, the term is inadequate. A member of a giant union such as the United Auto Workers is hardly free to choose whether or not to strike. And the term invites an arbitrary distinction between a strike which is a voluntary union action, and a lockout, which causes involuntary unemployment for union members. See generally Williams, The Labor Dispute Disqualification-A Primer and Some Problems, 8 VAND. L. REv. 338, 355 (1955).

Go See H.R. REp. No. 1414, 87th Cong., 2d Sess. 15-16 (1962). 
Congress amended the AFDC-U program in $1967 .{ }^{61}$ It created a federal work program, ${ }^{62}$ removed from the states the power to define "unemployment" and "good cause," 63 and required for the first time that noncompliance with the work requirement be punished by denial of aid. ${ }^{64}$ Through these changes Congress intended to reduce the number of recipients whose unemployment was due not to economic causes but to personal inadequacies such as lack of education, skills, or motivation. ${ }^{65}$ Seen in relation to the provisions for provided job training and incentives to induce people to work or accept training, the HEW work requirement appears to limit the opportunity to refuse a job or training for "good cause." Criteria for determining "good cause" are limited to the physical capabilities of the recipient and to minimal standards of health and safety at the job site. ${ }^{66}$ The 1961 legislative purpose to prevent arbitrary work assignments appears to have been abandoned.

Strikers clearly do not fit within any of the categories of unemployed persons whom Congress attempted to assist through the AFDG-U program. A striker's unemployment is not directly caused by recession or inability to learn and hold a job. Rather, it results from the use of economic pressure to break a deadlock in collective bargaining. And the "good cause" exception to the work requirement was intended to cover situations unrelated to work stoppages resulting from collective bargaining.

More generally, Congress did not anticipate that the AFDC-U program would benefit large groups of persons of proven work ability who were temporarily unemployed. The legislative history and the requirements of the program assume that unemployment compensation will provide the major source of relief to such persons. ${ }^{67}$ The program

61 Act of Jan. 2, 1968, Pub. L. No. 90-248, § 207(b)(1)(B), 81 Stat. 821, amending 42 U.S.C. \& 607 (1964) (codified at 42 U.S.C. \& 607(b)(1)(B) (1970)).

6242 U.S.C. $\$ \S 602(a)(19), 607(b)(2)$ (1970).

63 The Senate Finance Committee explained the reason for the change:

A major characteristic of the existing law is the authority left to the states to define unemployment. The Committee believes that this has worked to the detriment of the program because of the wide variations in definition used by the states .... The amendment proposed by the committee would authorize a federal definition of unemployment by the Secretary and would tie the program to the work incentive program established by the bill.

S. REP. No. 744, 90th Cong., Ist Sess. (1967).

6442 U.S.C. $\$ \S 602(a)(19)(\mathrm{F}), 607(\mathrm{~b})(2)(\mathrm{C})(1)(1970)$.

65 See Hearings on H.R. 5710 Before the House Comm. on Ways \& Means, 90th Cong., 1st Sess., pt, I, at 364-65 (1967) (statement of HEW Sec. John Gardner).

6845 C.F.R. \& 233.100(a)(3)(ii) (1971).

67 AFDG-U benefits are denied where the father is receiving unemployment compen- 
is directed at persons who have exhausted unemployment compensation benefits for which they are eligible rather than those who have disqualified themselves through participation in a strike. That Congress did not intend to depart from the practice, nearly universal under unemployment compensation programs, of denying aid to strikers may be seen in its use of such terms as "involuntary unemployment," which are typically used to justify denying unemployment compensation to strikers. ${ }^{68}$ Further support for this view may be seen in an analysis of the administrative structure of the AFDG-U program, which appears especially ill-suited to dealing with the needs of strikers.

3. Eligibility Requirements. Contrary to the Minter court's assumption, formal compliance with the eligibility requirements of the AFDC-U program does not insure that grants to strikers will serve the basic purposes of the program. This is particularly evident with respect to three factors: (1) the work requirement, (2) the income and asset tests, and (3) the administrative capabilities of the program.

First, the Minter court asserted that since striking AFDC-U recipients must register for alternate work they cannot be considered as persons not seeking employment. In practice, however, job registration for a striker is often an inconsequential formality. Some states do not require a worker to accept a job that would jeopardize his union standing. ${ }^{69}$ And where state officials observe the work requirement, it may have no effect on welfare enrollment for the practical reason that employers usually do not hire men for the short strike period. ${ }^{70}$ Such problems are particularly acute where the struck employer is the major employer in the area. Thus, during the 1970 United Auto Workers strike against General Motors, half of those required to register for job training in Michigan could not be trained because the demand exceeded the state's capacity. ${ }^{71}$ At best, work requirements are administered sporadically and unevenly because

sation. 42 U.S.C. $\S 607(\mathrm{~b})(2)(\mathrm{C})(\mathrm{ii})$ (1970). President Kennedy, in originally proposing the program, explained that it was aimed at persons who had exhausted such benefits. 107 CONG. REC. 1677, 1679 (1961).

68 All but two states deny unemployment compensation to strikers. See authorities cited note 3 supra. Courts and legislatures traditionally justify this denial on the ground that strikers are voluntarily unemployed. See Mandelker, supra note 11, at 488-91 and authorities cited therein; note 59 supra.

69 E.g., Letter from L.J. Burger, Director of Assistance Payments, Colorado Division of Public Welfare, to The University of Chicago Law Review, Sept. 17, 1971.

70 E.g., Letter from Richard E. Lightner, Executive Assistant for Public Relations, Ohio Department of Public Welfare, to The University of Chicago Law Review, Sept. 30, 1971.

71 Affidavit of Herbert P. Northrup, supra note 7, at 20. 
much discretion is left to the state administrator under the vague federal regulations.

Second, the income and asset tests used to determine eligibility for the AFDG-U program are not suited to measuring the real extent of a striker's need. One reason for this is that state asset requirements vary greatly throughout the country. ${ }^{72}$ During the 1970 UAW strike against GM, for example, AFDC-U benefits were granted to about thirteen percent of the strikers in Michigan ${ }^{73}$ but to no more than two percent of the strikers in Illinois. ${ }^{74}$ One explanation of this difference is that Michigan granted benefits to persons with as much as fifteen hundred dollars in liquid assets ${ }^{75}$ whereas Illinois denied aid to persons with more than three hundred dollars in such resources. ${ }^{76}$ In another Illinois program, in which a fifteen hundred dollar ceiling was imposed, thirty-six percent of the strikers were eligible to participate. 77

Moreover, although the asset requirement can be a critical bar to eligibility for the AFDG-U program, its importance may be diminished and its function distorted in the strike context. Local administrators often exempt strikers from more restrictive aspects of the asset requirement. In some states recipients are permitted by regulation to defer the disposition of nonhomestead property or life insurance if reemployment is imminent. ${ }^{78}$ In other cases officials are so burdened by administrative difficulties in processing large numbers of strikers' applications that few possible sources of assets are investigated. ${ }^{79}$

Above all, union members are less dependent on liquid assets than

72 See note 42 supra. For example, levels of income below which a state will grant AFDC-U assistance vary in the continental United States from $\$ 380$ per month in California to \$218 per month in Oklahoma. NATronal Cenrer for Social Statistics, Trends IN AFDC, Table 4 (NCSS Report No. D-2, Mar., 1971) [hereinafter cited as NCSS REPORT].

73 Letter from Leland E. Hall, Deputy Director, Research and Program Analysis, Michigan Department of Social Services, to The University of Chicago Law Review, Sept. 28, 1971 [hereinafter cited as Hall Letter].

74 F. Langille, Welfare Benefits for Strikers 4, Aug. 27, 1971 (Illinois Institute for Social Policy Memorandum) [hereinafter cited as Mlinois Memorandum].

75 Telephone interview with Keith Grove, Deputy Director, Genessee County Department of Social Welfare, Oct. 15, 1971 [hereinafter cited as Grove Interview]. Genessee County contains Flint, Michigan, where 60,000 of the 170,000 strikers lived.

76 Illinois requires applicants to have expended all liquid assets except $\$ 150$ for the first family member and $\$ 50$ for each additional family member, or $\$ 300$ for a family of four. ILL. DEP'T of Pub. Aid REg. \$ 10.03.04 (1966).

77 The program was food stamps. Illinois Memorandum, supra note 74 , at 4 .

78 E.g., ILL. PUB. ATD CODE § 1076 (1966). Recipients may be required, however, to borrow on their nonhomestead property or their insurance. In Michigan, on the other hand, only liquid assets are considered. Grove Interview, supra note 75.

79 See text at notes 86-92 infra. 
are other unemployed indigents. Banks and lending institutions often agree with unions to forestall members' major debts, such as home mortgages. ${ }^{80}$ Strikers retain their memberships in medical, insurance, and pension programs established by both unions and employers. ${ }^{81}$ And most unions are willing to distribute additional aid to members who experience extreme emergencies. ${ }^{82}$

The fact that a striker meets the income requirement may also be misleading. Welfare administrators usually calculate income need on a monthly basis. ${ }^{83}$ Consequently, a person with a widely fluctuating but nevertheless substantial income may qualify for benefits whereas a person with a regular but marginal income may not. Thus, a striker who has earned ten thousand dollars in the first eleven months of a year and has not saved more than is allowed under the applicable asset requirement may strike in December and still collect the maximum welfare grant because for welfare purposes his income during the strike is zero.

The fluctuating income of strikers contrasts with the income situation of nearly all other indigents eligible for the AFDG-U program. Many persons who receive benefits work full time most of the year, but their income is kept close to the poverty line by factors such as low wages, regional underdevelopment, discrimination, and large families. ${ }^{84}$ Many others earn an income slightly above the poverty line but do not receive benefits because they work the entire year. ${ }^{85}$ Workers who receive benefits solely because their income is reduced by a strike constitute a separate class of "temporary" indigents who would otherwise not be eligible for the program.

Third, the procedures for administering the current AFDG-U program are ill-suited for properly dealing with strikers. The eligibility of strikers strains welfare administration, creates unusual costs, permits fraud, and detracts from the service normally given other indigents.

Application procedures have generally been simplified during the last decade to protect the feelings of applicants and to remove from

80 Harsh \& Robinson, Little Impact Seen in 90-day Steel Strike, Chicago Sun-Times, Aug. 1, 1971, at 8, col. 1. See also State of Cal. Social Welfare Board, Postrion StateMENT: Issue, AID to STrikers 6 (1971) [hereinafter cited as California Position StateMIENT].

81 California Position Statement, supra note 80, at 8.

82 F. Briggs, supra note 8.

83 The federal AFDC-U statute, for example, speaks in terms of monthly calculations. 42 U.S.C. §§ 602-03 (1970).

84 HEINEMAN REPORT, supra note 6, at 22-33.

85 Id. 
them the burden of proving eligibility. Many states and all federal regulations permit a simple declaration of eligibility to suffice for the initial filing, to be followed by a confirmation of the applicant's financial statements. ${ }^{86}$ But officals are not equipped to process and investigate the large number of applications filed during a major strike. ${ }^{87} \mathrm{Be}-$ cause of the multitude of applicants and the similarity of their financial circumstances, applications are made in groups or in "mass." Although efficient, this procedure discourages investigations of applicants' statements either prior to or after filing and receipt of benefits. ${ }^{88}$ Liberal application procedures designed to protect inarticulate applicants are thus highly susceptible to abuse by highly organized and wellinformed unions.

More flagrant abuses occur when officials must move the welfare office into the union hall to speed the application process. Often union members themselves must be used to screen applicants and to process applications. ${ }^{89}$ The potential for inaccuracies and fraud in welfare administration during strikes may be inferred from studies made

8645 C.F.R. § 205.20 (1971).

87 A comprehensive discussion of the administrative headaches caused by the sudden influx of strikers is found in A. ThIFrLot \& R. CowiN, supra note 11 .

88 "Mass" application describes a simplified procedure whereby each applicant is requested to provide less information than would otherwise be required. See CaliforNia Position Statement, supra note 80, at 6-7.

It is time-consuming to question each applicant in detail concerning his application statements or to determine whether he fully understood what information he was required to divulge. In the rush of completing applications during a strike, such inquiry may be impossible. During the UAW strike, for example, Michigan officials were so pressed for time that they were unable to question even those applicants whose statements plainly indicated some sizable assets, such as residence in a well-to-do neighborhood. Grove Interview, supra note 75.

Moreover, although follow-up investigations or at least sample surveys are a requirement of nearly all welfare programs, they must often be ignored in the strike situation. For example:

Speaking before the California State Social Welfare Board, a management representative of the California and Hawaiian Sugar Company said, ". . At the time our strike started on June 1, 1970, $958(80 \%)$ members of the striking union were members, with savings, of the company-sponsored Federal Credit Union. Yet during the 17 week strike, we received only five telephone calls from welfare offices investigating applicants' eligibility for benefits."

A. Thieblot \& R. Cowrn, supra note 11.

States that have experienced these problems have sometimes changed their practices. Michigan, for example, now requires applicants to present bank books as evidence of their assets. Grove Interview, supra note 75. California authorities have encouraged county officials to make preliminary inquiries prior to allowing persons to file an application. California Position Statement, supra note 80, at 6.

89 For example: "Local 65 at the U.S. Steel Corp. South Works plant [in Chicago] has 400 trained counselors ready to aid strikers. Indiana welfare staffers have been training steel workers as temporary welfare clerks for months." Harsh \& Robinson, supra.note 80. While the potential for abuse is recognized, officials have been unsuccessful in safeguard- 
of the food stamp program. In Flint, Michigan, where sixty thousand GM workers were on strike in 1970, a study of five hundred sample food stamp cases revealed between seventy-five and one hundred duplicate allotments. Officials explained that the chaos caused by the surge of strikers into the welfare offices enabled some to apply for and receive food stamps at two or more offices without being discovered until months later. ${ }^{90}$ And recently over three hundred thousand dollars in food stamps were claimed to have been fraudulently acquired by Teamsters strikers in Illinois in $1970 . .^{21}$ In comparison, the national average of frauds in nonstriker welfare cases is only about two percent. ${ }^{92}$

The administrative difficulties caused by striker participation in the AFDC-U program inevitably affects other indigents dependent on the welfare system. During a strike officials usually give priority to strikers' applications, thus reducing the number of man-hours that can be devoted to other applicants. ${ }^{93}$ Moreover, the sudden and sometimes unpredictable rush of strikers into a program creates budgeting difficulties and may even reduce the amount of funds available for other indigents. ${ }^{94}$ Already many states cannot afford to give enough aid to meet one hundred percent of each applicant's need,95 and where total AFDC-U funds are insufficient, administrators are required to reduce

ing this kind of operation. The problem was voiced by an official of the Genessee County Department of Public Aid, which processed a significant portion of Michigan's UAW welfare applications in 1970: "When ten men in a row come in and all say they have exactly fifteen hundred dollars in the bank, the maximum for eligibility, you begin to wonder whether some union officials, instead of screening their men to see if they are eligible, actually tell the men what to say so that they will become eligible." Grove Interview, supra note 75.

$90 \mathrm{Id}$.

91 Among the reasons listed for the grants was the giving of false information by strikers. Chicago Daily News, Nov. 1, 1971, at 4, col. 1.

92 Paper delivered by Prof. Sydney E. Bernard before the National Conference on Social Welfare, San Francisco, Cal., May, 1968, in Hearings on Income Maintenance Programs Before the Joint Economic Comm. of Congress, 90th Cong., 2d Sess. 531-32 (1968).

93 Illinois Memorandum, supra note 74. Even where strikers are not given preferential treatment, the nonstriking poor may suffer. In the Westinghouse strike, for example, officials closed office doors at 10:00 each morning to process the large number of applications, thus inconveniencing other recipients and nonunion applicants. A. THuEbLot \& $R$. Cowis, supra note 11 .

94 Although a strike may be anticipated, it can never be predicted with certainty. Consequently, welfare offices must prepare months in advance for an eventuality that may never occur or, if it occurs, lasts for an unpredictable length of time. A. THIEBLor \& R. CowiN, supra note 11; Harsh \& Robinson, supra note 80. And the major reason California recommended that its county departments exclude strikers from welfare programs was the fear that a single strike could deplete the budget of a local office. CatirorNIA Posirion Statement, supra note 80 , at 3.

Q5 See NCSS REPORT, supra note 72. 
grants to individuals proportionately..$^{96}$ Thus, although strikers receive aid for questionable reasons, they jeopardize the amount of benefits received by more needy persons. ${ }^{97}$

4. Summary. The eligibility requirements of the AFDC-U program are not explicitly determinative of striker eligibility, and there is no clear congressional mandate to aid strikers. Moreover, mere formal compliance by a striker with the statute does not insure that the purposes of Congress will be adhered to because work, asset, income, and administrative requirements are in many respects not satisfied by strikers. Thus, although strikers are not clearly ineligible under the AFDC- $U$ regulations, the federal interest in aiding them is questionable, and a court might wish to construe the statute as excluding strikers in order to avoid a conflict between the AFDG-U program and the NLRA.

\section{B. General Assistance}

Many states grant benefits to able-bodied, working-age, unemployed males under General Assistance programs funded and controlled entirely by the state or its localities. As is the case with the AFDC-U program, General Assistance legislation does not refer explicitly to strikers and contains vague work requirements. Benefits may be denied to persons who fail without "good cause" 98 to accept employment or who refuse employment which is "suitable" ployable."100 Such language invites conflicting interpretations and

96 Cf. Rosado v. Wyman, 397 U.S. 397 (1970).

97 The amount of welfare payments to strikers is a minute fraction of the total annual aid granted to other groups of poor persons, in terms of both state and national totals. See National Center for Soctal Statistics, Semi-Yearly Report on Welfare Openings AND Closings (Aug., 1969). The upsurge in striker participation in welfare programs has come, however, at a time when states and localities are significantly reducing welfare appropriations and imposing increasingly rigorous work requirements. N.Y. Times, Aug. 16,1971 , at 1 , col. 5. This phenomenon represents a shift of priorities away from the poor that may be difficult to justify.

98 The statute in Minter is representative of General Assistance legislation: "No person shall be eligible for aid ... who willfully fails without good cause, as determined by the department, to maintain ... registration for work . . or to accept a referral to or offer of suitable employment." Mass. ANN. LAws ch. 117, § 1B (1965) (emphasis added). A survey of the language of state work requirements is tound in Mandelker, supra note 11, at 481.

99 "A person who is employable must register for employment or additional employment and accept offers of suitable employment . . . ." 23 ILt. STAT. ANN. § 6-1.4 (1966) (emphasis added).

100 "No assistance or care shall be given to an employable person who has not registered with the nearest local employment agency ... or has refused to accept employment in which he is able to engage." N.Y. SOC. Welfare LAw § 131(4) (McKinney 1966) (emphasis added). 
permits local welfare administrators wide discretion to decide whether to grant benefits to strikers. ${ }^{101}$ Eligibility may vary between localities within a single state ${ }^{102}$ and between states with similar welfare statutes. ${ }^{103}$ Nevertheless, some benefits are granted to strikers in at least thirty-one states. ${ }^{104}$

Although General Assistance programs, unlike the AFDG-U program, are not limited to persons with dependents, state work requirements are more demanding than their federal counterparts because they often include makework projects which do not aim to train or rehabilitate participants. ${ }^{105}$ As in the AFDG-U program, the obvious legislative intent to reduce the disincentive effects of welfare on unemployment ${ }^{106}$ seems inconsistent with striker eligibility. Other criteria for eligibility, such as income and asset and administrative requirements, are as ill-suited for properly dealing with strikers as they are in the AFDC-U program. ${ }^{107}$ It is questionable, therefore, whether the

101 Indeed, most statutes assign to the welfare administrator the task of determining striker eligibility. E.g., Mass. ANN. Laws ch. 117, \& 1B (1965).

102 E.g., Letter from Donald K. Johnson, Administrator of Public Assistance, Department of Social Services, North Dakota, to The University of Chicago Law Review, Sept. 28, 1971. Moreover, state administrators often do not have the power to compel local agencies to comply with state policies. E.g., Letter from Clarence Terpstra, Supervisor, Old Age Assistance and General Relief, Minnesota Department of Public Welfare, to The University of Chicago Law Review, Sept. 20, 1971 [hereinafter cited as Terpstra Letter].

103 Missouri grants benefits only to an "unemployable person." Mo. Star. ANN. \& 208.150 (1969). This has been interpreted to exclude strikers. Letter from John F. Pletz, Assistant Director, Missouri State Department of Public Health and Welfare, to The Universily of Chicago Law Review, Sept. 17, 1971. Minnesota grants benefits under the same language. MiNN. STAT. § 256.12 (1967); Terpstra Letter, supra note 102.

104 ALASKa STAT. \$ 47.25.120 (1966); CAL. WeLF. \& INST'NS CODE $\$$ 11000-183, 17000-09 (1966); Colo. Rev. Stat. ANN. § 119-1-2 (1969): Del. Code ANn. tit. 31, § 504(4) (1953); HawaIr Rev. Laws §§ 346-71 to -73 (1968); Ill. Rev. Stat. ch. 23, § 401 (1969); Kan. Stat. AnN. § 39-709 (1969): Kx. Rev, Stat. § 205.200 (1962); Me. Rev. Stat. AnN. tit. 22, § 851-4831 (1964); MD. ANn. Code art. 88A, § 17 (1957); MAss. Gen. LAws ANn. ch. 117 (1968); Mich. Stat. ANN. §§ 16.401 et seq. (1968); Minn. Stat. § 256.12 (1967); Mont. Rev. CODEs ANN. § 71-301-14 (1971); NEB. Rev. Stat. § 68-701 et seq. (1968); Nev. Rev. Stat. $\S \S$ 428.010-.110 (1968); N.H. Rev. STAT. ANN. §§ 126A:1-:24 (1964); N.J. REv. Stat. §§ 44:8-:109 (1937); N.Y. Soc. Welfare LAW § 131 (MrcKinney 1966); N.D. Cent. CodE \$\$ 50-01-01 et seq. (1960); OHro REv. ANN. \$ 5113.04 (Page 1971); OKLA. Stat. ANN. tit. 26.7 (1969); Ore. Rev. Stat. \$§ 411.710-.755 (1969); Pa. Stat. ANn. tit. 62, §§ 401-32 (1967); S.D. Compiled LAws ANN. § 28-13-1 (1967); UtAh Code ANN. § 55-15-21 (1963); VT. Stat. ANN. tit. 33, § 2701 (1967); WASH. Rev. CODE $\$ \S 74.08 .025-.40$ (1963); W. VA. CODE ANN. § 9-1-2 (1963); Wro. STAT. ANN. § 42-2 (1957).

105 See generally B. SteIN, ON RELIEF 42-71 (1971). Recently states have begun imposing unusually demanding work requirements on welfare applicants. N.Y. Times, Aug. 16,1971 , at 1 , col. 5 .

108 P. Dodyk, Income Maintenance: CASEs and Materials 141 (1969).

107 Since the states that grant AFDC-U benefits to strikers also comprise most of the states that grant General Assistance benefits to strikers, many of the same offices administer both programs. See statutes cited notes 52, 104 supra. 
state interest in granting General Assistance benefits to indigent strikers is any more compelling than the federal interest in making similar payments under the AFDG-U program.

However, as long as the administrator acts within his discretionary power in interpreting the statute and the work requirement is not so restrictive that it would be patently inconsistent to make strikers eligible for the program, state grants of welfare to strikers should probably be found to represent a "substantial" state interest. To aid indigents is generally recognized as a basic duty of the state. ${ }^{108}$ It is similar in importance to the police and taxing powers, which the states may exercise with minimum federal interference in order to protect the health and well-being of their citizens. ${ }^{109}$ Although the Minter court's argument that welfare grants to strikers prevent economic stagnation and deter violence is not persuasive, ${ }^{110}$ its presumption of a substantial state interest in making such grants and its reluctance to preempt them is well-founded. ${ }^{111}$

\section{The Impact of Welfare on Collective Bargaining}

\section{A. The National Labor Relations Act}

State and federal statutes may be invalidated or narrowly construed in order to preserve the collective bargaining framework established by the NLRA. States may be preempted from interfering with activities "arguably subject to $\S 7$ or $\S 8$ of the Act"112 or from acting in a way that would "operate to frustrate the purpose" of the NLRA.113 Federal law that conflicts with the Act may be restrictively interpreted to maintain the federal labor policy. ${ }^{114}$

108 See, e.g., Taunton v. Talbot, 186 Mass. 341, 71 N.E. 785 (1904); People of Peoria City v. Hill, 163 Ill. 186, 46 N.E. 796 (1896).

109 Cf. West Coast Hotel Co. v. Parrish, 300 U.S. 379, 398-99 (1937) (state power to establish minimum wage upheld); Colorado Anti-Discrimination Comm'n v. Continental Airlines, 372 U.S. 714 (1963) (state antidiscrimination law upheld despite federal law regulating the same activity).

$110435 \mathrm{~F} .2 \mathrm{~d}$ at 933 . Since the amount of benefits, if paid to strikers, varies greatly among states, the deterrent effect of welfare grants is uncertain. On the other hand, violence might indeed occur if individual strikers expecting welfare payments were denied eligibility by local officials, and economic stagnation might as easily occur in a long, drawn-out strike perpetuated by welfare payments.

111435 F.2d at 994.

112 San Diego Building Trades Council v. Garmon, 359 U.S. 236, 245 (1959); see note 26 supra.

113 Teamsters Local 20 v. Morton, 377 U.S. 252, 258 (1964).

114 See United States v. Hutcheson, 312 U.S. 219 (1941) (Sherman Act held inapplicable to certain concerted labor activities notwithstanding their restraint of trade); Allen Bradiley Co. v. Local 3, IBEW, 325 U.S. 797 (1945) (union activity assisting management 
The question of welfare grants to strikers is not specifically referred to by the NLRA, as amended.115 The original House version of the bill would have denied unemployment compensation to strikers while allowing them to receive local welfare benefits. ${ }^{116}$ This language was eliminated from the final bill, ${ }^{117}$ indicating a congressional reluctance to regulate public grants to strikers. It is arguable, however, that Congress might not have abstained from regulating AFDC-U grants to strikers had it foreseen that the number of states making such payments would far exceed the number granting unemployment compensation to strikers in $1947 . .^{118}$ Judicial review may be appropriate to eliminate conflict between the NLRA and newly created legislation which the Taft-Hartley Act did not anticipate and which Congress has failed to clarify. The entire preemption doctrine, in fact, is largely a judicial creation. ${ }^{119}$

The phrase "free collective bargaining"120 does not appear in the NLRA, but it is present throughout the legislative history, ${ }^{121}$ and courts have adopted it as a basic tenet of the Act. ${ }^{122}$ Bargaining can be free only if the government sanctions unionization and creates a rough equality of bargaining strength between labor and management. ${ }^{123}$ One of the basic purposes of the NLRA is to strike a balance of power, however elusive, between the parties by creating a framework for the collective exertion of economic force. ${ }^{124}$ The central in-

in creating a market monopoly held violation of Sherman Act after judicial balancing of the legislative purposes of labor and antitrust legislation).

11529 U.S.C. $\S \S 141$ et seq. (1970).

110 The House Report explained the measure as follows:

A few states pay strikers after the fifth, sixth or seyenth week of a strike. This is clearly a perversion of the social security laws, which Congress intended to provide for those out of work involuntarily and through no fault of their own. We therefore have provided that a striker's status as an "employee" stops when he starts receiving unemployment compensation from any State. He may receive relief from his union, from local welfare funds, or from charity without losing that status.

I NLRB, Legislative History of the Labor Management Relations Act, 1947, at 303-04 (1947).

11729 U.S.C. $\$ 152(3)(1970)$.

118 Compare Shadur, supra note 3, at 317 n.100, with statutes cited notes 52, 104 supra. 119 "The principle of preemption ... was born of this Court's efforts, without the aid of explicit Congressional guidance to delimit state and federal authority over labor disputes." Amalgamated Ass'n of Street Employees v. Lockridge, 91 S. Ct. 1909 (1971).

120 The terms "government neutrality" and "freedom of collective bargaining" were used interchangeably by the court and counsel to describe the federal labor policy jeopardized by welfare grants to strikers. 435 F.2d at 991-93.

121 See S. Rep. No. 105, 80th Cong., Ist Sess. 2, 13 (1947); 93 Cong. Rec. 3835 (1947) (remarks of Sen. Robert Taft).

122 Cf. NLRB v. American Nat'l Ins. Co. 343 U.S. 395, 401-02 (1952) (dictum).

123 See generally $\mathrm{H}$. Wellington, LABor and The LEgal. Process 26-46 (1968).

124 See 29 U.S.C. $\$ 141$ (1970); The following remarks of Senator Taft are indicative: 
quiry; then, is whether state welfare grants to strikers so alter the statutorily constructed framework that they frustrate this purpose of the Act.

Section 7 of the NLRA protects the right of employees to organize and strike. ${ }^{125}$ But the Supreme Court has declared that "nothing in the Act gives employees the right to insist on their contract demands free from the sort of economic disadvantage which frequently attends bargaining disputes." 126 Thus, the employer may resort to the economic weapons at his command, incluiding the replacement of striking workers ${ }^{127}$ and a lockout in anticipation of a strike. ${ }^{128}$ It has been suggested that the Supreme Court evaluates the legality of the employer's weapons by balancing the legitimate business needs of the employer against the organizational interests of the union, in effect carefully adjusting the bargaining power of the two parties. ${ }^{129}$ On the other hand, the NLRB is forbidden to adjust the weapons available to either side if the purpose of the adjustment is to affect the substantive terms of agreement. ${ }^{130}$

Thus, the NLRA as interpreted by the courts achieves a balance of economic power only to the extent of creating a general framework for labor-management bargaining. The Act brings the parties together in a bargaining relationship, but once that relationship has been established the parties are free to exert economic weapons to achieve their ends. ${ }^{131}$ Calculation of the extent to which welfare grants to strikers "frustrate" the purpose of the NLRA must, therefore, be inexact. It

Our aim should be to get back to the point where, when an employer meets with his chepluyces, they have substantially equal bargaining power, so that neither side feels he can make an unreasonable demand and get away with it. . . If there is reasonable equality at the bargaining table, I believe there is much more hope for labor peace.

1 NLRB, supra note 116 , at 1007 .

12529 U.S.C. $\S 157$ (1970). It has been suggested that in the area of peaceful strikes for higher wages, "Congress occupied this field and closed it to state regulation." International Union, UAW v. O'Brien, 339 U.S. 454, 457 (1950). O'Brien and cases like it dealt, however, with state regulation restricting the freedom to strike and should not be taken as controlling a case such as Minter, in which state action increases the union's ability to strike. See generally Meltzer, The Supreme Court, Congress, and State Jurisdiction over Labor Relations, 59 CoLuM. L. REv, 1, 12-13 (1959).

126 American Shipbuilding Co. v. NLRB, 380 U.S. 300, 313 (1965) (dictum).

127 NLRB v. MacKay Radio \& Tel. Co., 304 U.S. 333 (1938).

128 American Shipbuilding Co. v. NLRB, 380 U.S. 300 (1965).

129 Christensen \& Svanoe, Motive and Intent in the Commission of Unfair Labor Practices: The Supreme Court and the Fictive Formality, 77 YALE L.J. 1269, $1314-42$ (1968).

130 See H.K. Porter Co. v. NLRB, 397 U.S. 99 (1970); NLRB v. Insurance Agents Int'I Union, 361 U.S. 477, 490 (1960).

131 See generally Comment, Picket Line Observance, the Board and the Balance of Interests, 79 YALE L.J. 1369, 1375-80 (1970). 
must be based on the effect of such grants in shielding recipients from the economic pain of a strike, thereby strengthening the union's weapon and weakening the position of the employer. Empirical evidence of the type suggested by the Minter court will be helpful in measuring more exactly the effect of welfare grants on collective bargaining.

\section{B. The Economic Impact of Welfare}

1. Amount of Welfare Benefits Received by Strikers. Only a few heavily industrialized states fail to grant either AFDC-U or General Assistance benefits to strikers. ${ }^{132}$ And although few welfare agencies maintain statistics revealing the number of strikers receiving welfare benefits, there is ample evidence that strikers are utilizing these programs extensively. ${ }^{133}$ The strike in the Minter case resulted in twentyfive percent striker participation in the AFDC-U and General Assistance programs. ${ }^{134}$ In the strike at Westinghouse Steam Division in Lester, Pennsylvania in 1970-71, roughly twelve percent of the strikers received AFDC-U benefits and more than half received General Assistance benefits. ${ }^{135}$ During the UAW strike in 1970 , more than 23,000 of the 170,510 Michigan strikers or about fourteen percent received AFDC-U benefits and more than 5,000 or about three percent received General Assistance benefits. ${ }^{136}$

Welfare benefits may offset a substantial part of a worker's loss of earnings due to a labor dispute. Except in four states, a striker who qualifies for AFDC-U or General Assistance benefits is also eligible

132 Compare statutes cited note 104 supra with statutes cited note 52 supra. The largest such states are Texas, Wisconsin, Missouri, Florida, Indiana, and Louisiana.

133 Welfare agencies with few exceptions do not maintain statistics revealing striker participation in the programs. Only four states replying to inquiries code their welfare records to reveal the number of strikers who apply: California (certain counties only), Michigan, Illinois, and New York. Data on file at The University of Chicago Law Review.

Conclusions in this section are based on a review of statistics from five major strikes: the 1970 UAW strike in Michigan; the 1969-70 strike against General Electric in New York; the New York City newspaper strike of 1962-63; the 1970-71 strike against Westinghouse Steam Division in Lester, Pennsylvania; and the 1970 Teamsters strike in Illinois.

Primary focus is placed on the UAW strike because of the availability of statistics on all its aspects. The UAW strike represents a major effort by a highly organized, politically powerful union to take advantage of liberal welfare policies in one state. On the other hand, the UAW pays substantial strike benefits and consists of members with a higher average income than those of many unions. Consequently, some of the limitations of welfare in alleviating the economic pain of a strike, as well as some of its potentialities, will become apparent. For a complete review of the economic effects of welfare on collective bargaining, see A. ThIEblot \& R. Cowin, stpra note 11 .

134 See text at notes 16-17 supra.

135 A. ThIEblot \& R. Cowin, supra note 11 . Of twenty-two hundred striking workers in one county, almost two thousand received food stamps. $I d$.

136 Hall Letter, supra note 73. 
for food stamps. ${ }^{137}$ The food subsidy may amount to $\$ 108$ in stamps per month for a four-member family receiving less than $\$ 360$ monthly in welfare and less than $\$ 30$ monthly in other income. ${ }^{138}$ In Pennsylvania, for example, where the average gross weekly earnings of a production line employee are $\$ 141,139$ the maximum AFDG-U payment to a family of four is $\$ 313$ per month, ${ }^{140}$ so that a full allotment of food stamps would permit a striker eligible for AFDG-U benefits to recoup about sixty-five percent of his normal gross income and about seventy-five percent of his net income after deductions. ${ }^{141}$ In Michigan the maximum monthly aid available under the AFDG-U and food stamp programs during the UAW strike was more than half of the average striker's gross prestrike income and about sixty-three percent of his net disposable prestrike income. ${ }^{142}$ Although wage and welfare levels vary from state to state, these percentages are not unrepresentative of other heavily industrialized states. ${ }^{143}$ Thus, although welfare benefits do not fully replace earnings lost due to a strike, they do provide minimal financial security for the length of the strike. ${ }^{144}$

1377 C.F.R. $\$ 271.3$ (1970). The only states that do not participate in the food stamp or commodity programs are Arizona, Delaware, Massachusetts, Nevada, and New Hampshire.

13836 Fed. Reg. 14118 (1971). A nonwelfare recipient with an income of $\$ 100$ per month would pay $\$ 25$ for $\$ 108$ in food stamps. If his income rose to $\$ 170$ per month he would pay $\$ 56$ for the same amount of stamps. The amount of "free" stamps that can be purchased also varies in relation to family size and place of residence.

139 EMPLOYMENT \& EARNings, Sept., 1971, at 110.

140 NCSS REPORT, supra note 72.

141 . If weekly gross income is $\$ 142.09$, average income after deductions for federal tax and social security is $\$ 125.35$. EMPLOYMENT \& EARNINGs, Sept., 1971, at 110. Deductions for union dues, disability insurance, and state taxes might reduce spendable income to below $\$ 120$ per week. If the worker received a full AFDC.U grant of $\$ 313$ in addition to $\$ 108$ in food stamps, he would collect over $\$ 90$ per week, or seventy-five percent of his former spendable earnings. (Figures are based on a family of four.)

142 The maximum AFDC-U benefit paid to strikers in Michigan was $\$ 325$ plus an average grant of $\$ 46$ in food stamps, resulting in a tax-free grant of about $\$ 85$ per week. Hall Letter, supra note 73.

The average UAW member's wage prior to the strike was slightly more than four dollars per hour. Telephone Interview with Jerry Wilsie, UAW Office of Strike Insurance, Detroit, Michigan, Oct. 11, 1971 [hereinafter cited as Wilsie Interview]. Thus, combined AFDC-U and food stamp benefits of $\$ 85$ dollars per week would be about fifty percent of a forty-hour salary. If gross earnings are reduced fifteen percent by deductions to $\$ 136$ per week, welfare benefits would be about sixty-three percent of net earnings.

143 Maximum monthly AFDC-U payments (disregarding food stamps) for some key industrial states: Massachusetts, \$349; New Jersey, \$347; Washington, \$303; Michigan, \$293; Illinois, \$284; California, \$280; and Ohio, \$258. NCSS REPORT, supra note 72. Average weekly wages for production line employees in the same states: Massachusetts, \$134.80; New Jersey, \$147.60; Washington, \$168.52; Michigan, \$183.08; Illinois, \$158.57; California, $\$ 160.37$; Ohio, \$166.87. National average income for production line employees: $\$ 142.09$. EMPLOYMENT \& EARNINGs, Sept., 1971, at 108-11.

144 Some states grant welfare benefits equal to one hundred percent of the state-estab. 
2. Comparison with Strike Benefits. Although the average strike benefit granted to members varies greatly among unions, such benefits rarely approach the size of grants available to welfare recipients. Some unions do not pay any strike benefits while others pay benefits on an irregular basis, ${ }^{145}$ and only a few pay benefits almost equal to the union members' wages. ${ }^{146}$ A 1965 study of strike subsidies calculated the average union strike benefit to be about twenty dollars per week. ${ }^{147}$

Although individuals generally receive less from their union than from public sources, the aggregate amount of strike benefits occasionally exceeds the aggregate amount of welfare benefits. The UAW strikers in Michigan, for example, received over $\$ 4$ million in AFDG-U benefits and $\$ 12$ to $\$ 14$ million in food stamps. ${ }^{148}$ The union, however, dispensed over $\$ 60$ million in benefits to strikers in Michigan alone. ${ }^{149}$ On the other hand, if welfare recipients had not received $\$ 30$ to $\$ 40$ per week in strike benefits ( $\$ 172$ per month for the average welfare recipient), the amount received by union members from all welfare programs would have more than doubled because such aid is reduced to the extent of a recipient's outside income. ${ }^{150}$ In recognition of this

lished standard of need: Colorado, Illinois, Massachusetts, Michigan, New Jersey, Pennsylvania, and Washington. NCSS REPORT, supra note 72. The state standard of need is required to reflect living costs in the state. 42 U.S.C. \& 602(a)(23) (1970).

145 The International Union of Electrical Workers, for example, pays no benefits. A. Thierlot \& R. Cowin, supra note 11 . The United Steelworkers Union pays strike benefits only on the basis of need, and each local is given a limited fund to dispense at its discretion. Harsh \& Robinson, supra note 80.

146 The newspaper unions in New York are one example. N.Y. State DEP'T of LABor, The INDUSTRLAL CONTROVERSY IN NEW YORK CrTY NEWSPAPERS AND ITS EFfFect ON UNEMployment Insurance Claims (Research Bull. No. 3-63, 1963).

147 F. Briggs, supra note 8 , at 96 . This compares favorably with the up-to-date survey of transportation union benefits found in TRANSPORTATION Ass'N OF AMERICA, supra note 8 , at 5. At twenty dollars per week, the average union strike benefit is no greater than a maximum weekly allotment of food stamps. See text at note 138 supra.

148 Hall Letter, supra note 73.

149 During the ten-week strike, 170,000 workers received between $\$ 30$ and $\$ 40$ per week, for a total union expenditure of more than $\$ 60$ million. Wilsie Interview, supra note 142. Of course, the UAW is a wealthy union. And although only one of the UAW's three main divisions actually goes out on strike, the strike fund is created by the contributions of all three. In a different strike situation, a coalition of unions struck against GE in 1970 but were able to raise only $\$ 3$ million from their own resources. On the other hand, they were able to collect ten times as much from public sources. Gannon, supra note 1.

150 Hall Letter, supra note 73. Because the average welfare recipient received $\$ 172$ per month from his union, Michigan was required to pay an average of only $\$ 96.75$ per recipient of the $\$ 310$ to $\$ 325$ standard allowance. $I d$. All states replying to inquiries indicated that welfare grants are reduced to the extent that the recipient earns strike benefits from his union. Data on file at The University of Chicago Law Review.

If the state had been required to pay the full standard allowance to each recipient, the total amount of AFDG-U payments would have tripled to about $\$ 13$ million. Added to $\$ 14$ to $\$ 16$ million in food stamps, this would have resulted in a total public contribution 
fact, some unions distribute strike benefits unequally, so that members who would not qualify for welfare benefits receive most of the strike benefits. ${ }^{151}$

In comparing welfare and strike benefits, it is important to focus both on the different role each form of aid plays in the strike context as well as on the total amount of aid granted. Strike benefit programs include some disincentives to strike activity that are not present in welfare programs. Strike benefits are often withheld for a specified period of time or denied entirely if the strike violates union rules. ${ }^{152}$ Welfare payments, on the other hand, are usually made without a significant waiting period (and when a delay occurs are retroactive to the date of application) and without regard to the justification for the strike. ${ }^{153}$ Moreover, union members bear the full cost of strike benefits through union dues, whereas the cost of welfare benefits is shared with the public.

Only in unusual cases does the combination of welfare and strike benefits completely eliminate the economic pain of a strike for all union members. ${ }^{154}$ Where welfare benefits are available, however, the union member may count on a minimum level of economic support for the length of the dispute if at any time he depletes his assets and thereby becomes eligible for the program. Strike benefits may ease the burden of more well-to-do strikers who would never qualify for welfare programs, but such benefits are not substantial and union funds are not unlimited. That welfare benefits are inexhaustible has important implications for collective bargaining. It has been suggested that management prefers a long strike to a short one because labor's

to the strike of almost $\$ 30$ million. If the union had paid no strike benefits whatsoever, the total public bill would have been even higher since more strikers would have been eligible for the programs.

151 E.g., California Position Statement, supra note 80, at 8. Similarly, in New York, where all union members may receive unemployment compensation after seven weeks of strike, strike benefits may be granted in large amounts during the first few weeks and then reduced when public funds become available. N.Y. STATE DEP'T OF LABOR, supra note 146 , at 5 .

162 F. Briggs, supra note 8, at 95. See also Transportation Ass'N of America, supra note 8 , at 5 .

153 Replies to written inquiries suggest that delays of two weeks to one month are common in processing General Assistance applications but that the first welfare payment includes funds to cover the period between the dates of application and eventual payment. Data on file at The University of Chicago Law Review. Although the AFDC-U program imposes a thirty-day waiting period, strikers in most states may receive General Assistance benefits during that period.

154 One rare case in which union members almost recouped their entire loss of wages was the New York City newspaper strike of 1962-63. The largest source of striker aid came from uniop strike funds. N.X. STATE DEP'T of LABOR, supra note 146 , at 5. 
bargaining position is weakened when its funds are depleted by a strike. ${ }^{155}$ Thus, because welfare grants to strikers provide a constant source of funds, they alter the conditions of collective bargaining by robbing management of its "Iong strike option."

3. Effect on the Length of Strikes. In Minter both the court of appeals and the district court emphasized that the length of the strike is the test of the impact of welfare grants on collective bargaining. ${ }^{156} \mathrm{Al}$ though some evidence suggests that welfare grants may prolong a strike once it has begun, ${ }^{157}$ it is clear that the mere availability of benefits may have no effect at all on its length. The demands and bargaining tactics of the parties must be considered in connection with the strike's duration. ${ }^{158}$ Unions expecting public aid may increase their demands, which in turn may either prolong the strike or increase the cost of the final contract settlement. An employer may settle at any time, depending on his estimate of the union's resources and his willingness to accede to its demands.

The impact of welfare grants on collective bargaining may be better measured by another suggested test, that of the striker's "resolve." Although the concept is difficult to define, much less to measure, it represents the key question in labor-management negotiations, the point at which a party's determination to win further concessions is offset by its desire to avoid the economic pain of continued work stoppage. The resolve of union leaders is affected by the willingness of members to endure a strike, and the attitudes of the rank and file in turn affect those of their leaders. That the availability of welfare benefits is valued as a bargaining aid by both leaders and members may be seen from the emphasis the unions place on organizing their men to take advantage of public aid programs ${ }^{159}$ and the emphasis they have always placed on raising private union strike funds.

155 Livernash, The Relation of Power to the Structure and Process of Collective Bargaining, $6 \mathrm{~J}$. LAw \&: EcoN. 10, 14-18 (1963). According to this theory labor usually wins a short strike and management must choose between a long strike and no strike at all. It is argued that management "wins" after a long strike because labor's bargaining position collapses when it exhausts its resources. But of. Weber, The Structure of Collective Bargaining and Bargaining Power: Foreign Experiences, 6 J. LAw \&: EcoN. 79, 147 (1968).

150435 F.2d at $993 ; 318$ F. Supp. at 366.

167 During the GE strike nearly all strikers in New York received sixty-five dollars per week in unemployment compensation. At the end of the strike the New York locals voted to reject the eventual settlement terms while out-of-state locals voted to return to work. One account reported that if "out of state locals with no job insurance cushion ... [had not] approved the agreement overwhelmingly ... the GE strike might still be dragging on." N.Y. Times, Mar. 17, 1970, at 42, col. 2.

158 N. Chamberlain, supra note 13, at 97-111 (1958).

150 For many years the AFL.CIO Community Services Department has aggressively 
Reports from the scenes of strikes, by both the public press ${ }^{160}$ and labor experts, indicate that the availability of welfare may harden labor's bargaining position. A recent study which involved extensive interviews with labor and management officials concludes that there is substantial agreement on both sides of the bargaining table that welfare grants alter negotiating strategy. ${ }^{161}$ This conclusion has been endorsed by the Director of the Federal Mediation and Conciliation Service. ${ }^{162}$

4. Summary. The available evidence suggests that welfare grants in many states, especially AFDC-U benefits in combination with food stamps, substantially ease the economic pain of a strike for less wellto-do workers. Concomitantly, welfare grants reduce the strikers' fear of severe hardship and attenuate the disincentives to use of the strike weapon. It may be inferred although not proved that where welfare is available, unions make greater demands and strikes are more prolonged or settlements more expensive. The crucial factor is that management must recognize labor's increased willingness to endure a long strike and adjust its bargaining strategy accordingly. The framework for free collective bargaining established by the NLRA and the courts will thus have been altered by welfare grants to strikers.

\section{ITT v. Minter REEXAMINED}

\section{A. Preemption of State Welfare Administration}

In light of the previous analysis, the Minter court's balancing of the conflict between welfare and labor legislation merits careful reconsideration. The First Circuit declared that welfare grants would not be invalidated unless they "palpably infringe[d]" on the federal labor policy. ${ }^{183}$ Yet even if such infringement were shown, preemption might still not result if a "substantial" state interest were involved. ${ }^{164}$ Clearly, welfare grants to strikers infringe on the federal labor policy. That the court should not have doubted this but instead should have based

mobilized unions to take maximum advantage of public and private contributions to strike efforts. Gannon, supra note 1.

160 "The solidarity of the strikers seems to be a blend of many factors. . . . One of the most important is that many strikers receive wide support from a combination of public welfare, federal food stamps, and union strike benefits." N.Y. Times, Feb. 13, 1968, at 25, col. 4.

161 A. ThIEBLot \& R. Cowin, supra note 11.

162 Address by J. Curtis Counts, Director, Federal Mediation and Conciliation Service, before the National Association of Manufacturers Institute on Industrial Relations, June 14, 1971, in 77 LAB. REL. REP. 152 (1971).

163435 F.2d at 993.

184 IÁ. 
its decision squarely on the strong state interest involved and the desirability of an administrative or legislative solution to the problem may be seen in its discussion of two earlier cases.

In General Electric Co. v. Callahan, ${ }^{105}$ the First Circuit had previously voided a Massachusetts law authorizing a state board to investigate bargaining deadlocks and publish reports fixing responsibility for the stalemates. Finding that this procedure was designed to bring the "pressure of public opinion to bear" upon the parties, the court held that the law was in conflict with the federal labor policy "not to compel agreement, but instead only to encourage voluntary agreements freely arrived at after 'good faith' bargaining."168

The Minter court distinguished Callahan on the ground that it involved interference with section 8(d) of the NLRA and was therefore preempted under Garmon. ${ }^{167}$ The Massachusetts law violated section 8(d) because it was designed to compel settlement through the use of a fact-finding board with subpoena powers, the type of direct regulation of labor disputes that the Taft-Hartley Act took special pains to avoid. ${ }^{168}$ The Minter analysis was incomplete, however, because it failed to compare the use of public opinion, condemned as an economic weapon in Callahan, with the use of welfare grants as such a weapon. Although the precise impact of welfare grants on collective bargaining is difficult to calculate, it seems probable that they have a more direct and substantial effect than fact finding. ${ }^{169}$ Since the First Circuit had previously found the Callahan statute in conflict with the federal labor policy, it is inexplicable why that court subsequently had "substantial doubt"170 that welfare grants created a similar conflict.

Minter also approved John Hancock Mutual Life Insurance Co. $v$. Commissioner of Insurance, ${ }^{171}$ which had voided a state law exempting insurance policy holders from making premium payments until thirtyone days after a strike by agents who normally collect premiums. Although the statute was designed to protect policy holders from defaulting on their policies during strikes, it coincidentally deprived

165294 F.2d 60 (Ist Cir. 1961).

168 Id. at 67.

$167435 \mathrm{~F} .2 \mathrm{~d}$ at 991 n.4.

168 Compare 29 U.S.G. § 176 (1970) with 45 U.S.C. § 153 (1970). See also Case Note, 110

U. PA. L. REv. 620 (1962).

169 The efficacy of fact finding as a means of achieving a bargaining settlement has been sharply questioned. See ABA Ad Hoc Comm. to Study National Emergency DisPUTES, FINAL REPORT 818 (1966); Case Note, supra note 168, at 624.

$170495 \mathrm{~F} .2 \mathrm{~d}$ at 994.

171 \$49 Mass. 390, 208 N.E.2d 516 (1965). 
insurance companies of revenues. The Massachusetts Supreme Court admitted that the statute did not attempt to compel a settlement, as did the one in Callahan, but it invalidated the law, reasoning that "[it] gives the union a potent weapon which cannot fail unilaterally to restrict the desired bilateral freedom of collective bargaining, left free by Congress for the operation of economic force."172

Minter approved Hancock on the ground that "the conflict between federal and state interests and their relative importance ... [is] so clear as to render extended empirical exploration unnecessary." 173 The plaintiff insurance company in Hancock was, therefore, exempted from the rigorous burden of proof imposed on the employer in Minter. In this regard the court emphasized that the insurance law in Hancock required nonstriking agents to cease work in violation of their right not to engage in concerted activities and effectively prevented employers from hiring new agents to collect premiums. ${ }^{174}$ But the court here exaggerated the effect of the insurance statute since policy holders were not prevented from paying premiums to nonstriking agents or new employees. ${ }^{175}$ Moreover, the Hancock court had concluded that as long as the statute "tips the balance in favor of the agents in any labor dispute ... [i]t is as much a violation of Federal labor policy as it is for a state to attempt to regulate rights or duties specifically protected by the Federal Act."176

There is little to distinguish the effects of the two statutes on the balance of bargaining power. Welfare grants that replace strikers' lost earnings and insure them against destitution aid labor no less than does the temporary deferral of insurance companies' rights to receive premiums. It is difficult to see, therefore, why the Minter court imposed an elaborate burden of proof in the welfare situation but would have required no such burden in a situation such as that presented in Hancock.

Courts would do well to avoid comparison of such statutes in terms of their empirical impacts on the federal labor policy. Welfare and insurance laws are not the only kinds of legislation affecting the financial well-being of participants in a labor dispute. Statutes covering unemployment compensation, ${ }^{177}$ state and federal taxes, and medical aid

$172 I d$. at 403,208 N.E.2d at 524.

173435 F.2d at 993 n.9.

174 Id.

175 See Case Note, 66 Colum. L. REv. 391 (1966).

176349 Mass. at 403, 208 N.E.2d at 525-26.

177 State cases upholding local laws that deny unemployment compensation to strikers traditionally cite the need for states to remain neutral in labor disputes or not to inter- 
and housing programs also invite empirical analysis. To distinguish such statutes empirically would be no less difficult than to distinguish between welfare programs in different states, an approach which the Minter court rejected in favor of a macrocosmic solution.

The Minter court's interposition of an empirical burden of proof on the employer obscured the real basis for its decision, its assessment of the state interest in aiding indigent strikers. Minter distinguished Hancock as a case where "the need for the state statute [did] not clearly appear,"178 even though the Hancock court had observed that its ruling would apply even if the state had proven the need for the statute, ${ }^{179}$ and proof of state need was no more necessary in Hancock than in Minter since the insurance and welfare statutes each represented on its face a clear state interest. ${ }^{180}$ To distinguish the local interests is a difficult task, but such difficulties may be inherent in preemption decisions because of Congress's lack of guidance in the preemption field. ${ }^{181}$ In difficult cases, as the court recognized, it may be best to avoid preemption to allow the legislature to clarify its position. ${ }^{182}$ On this basis the Minter court's decision and its treatment of Hancock seem justified.

Preemption of a state's right to aid indigent strikers, regardless of the origin or extent of their need, would create a regulatory gap that could not be filled by substitute legislation. Even if such grants altered the federally established framework for collective bargaining, no court would desire immobilizing the state from providing for the health and well-being of workers affected by labor disputes. Preemption of the insurance statute in Hancock, on the other hand, does not prevent the state from creating an alternative solution with less impact on collective bargaining. When striking agents refuse to collect premium payments, policy holders could be required to pay monthly premiums directly to the company.

fere with free collective bargaining. Yet none of these cases resorts to an empirical test to uphold its reasoning. See, e.g., Matson Terminals, Inc. v. Employment Comm'n, $24 \mathrm{Cal}$. 2d 695, 707, 151 P.2d 202, 209 (1944); In re Klein, 15 App. Div. 2d 201, 203, 222 N.Y.S.2d 672, 674 (1961), aff'd, 12 N.X.2d 678, 185 N.E.2d 909, 233 N.Y.S.2d 471 (1962). See also Note, supra note 3 , at $88-92$ and authorities cited therein.

178435 F.2d at 993 n.9.

179349 Mass. at 404-05, 208 N.E.2d at 525-26.

180 See Case Note, supra note 175.

181 One commentator has called the treatment of preemption by the NLRA "frag. mentary and elusive." Meltzer, supra note 125, at 6. Another has suggested that this elusiveness was intentional. Cox, Labor Decisions of the Supreme Court at the October Term, 1957, 44 VA. L. REv. 1058, 1059 (1958).

182435 F.2d at 994. 
Minter. also rightly refused to exclude strikers from the AFDG-U program. This result is compelled not because the federal interest in granting AFDC-U benefits to strikers clearly outweighs the damage such grants inflict on the federal labor policy, but because Congress is the forum best suited for resolving the conflict between the two programs. A legislative solution might attenuate that conflict without sacrificing the basic goals of either program by, for example, reducing the number of strikers who receive aid for questionable reasons or by denying aid to strikers engaged in particular types of labor disputes. Even if the interests of either program must be sacrificed, Congress is better able than the court to weigh the essentially social and political factors involved.

\section{B. Legislative and Administrative Solutions}

The Minter decision frees the states to perpetuate the confusion that presently characterizes welfare administration in the strike context. Current practices not only alter the framework for collective bargaining but also place an intolerable strain on the language and administration of the welfare statutes. A legislative or administrative solution at the federal level is clearly required.

Several recent proposals to reform the welfare system, although made without specific regard to the problem of welfare for strikers, would further the federal interest in a uniform labor policy. Common to the Nixon Administration's modest Family Assistance Plan, ${ }^{183}$ and more far-reaching proposals such as the negative income tax system ${ }^{184}$ are the following improvements over the current programs: (1) establishment of a guaranteed annual income program, with uniform asset and income requirements, to be administered by federal authorities; (2) lengthening of the accounting period used to calculate income need from a month to three months or a year, ${ }^{185}$ with a provision that recipients refund overpayments so that persons with substantial but fluctuating incomes may not receive excessive aid; and (3) clarification or abolition of the work requirement, maintaining incentive to work

183 H.R. 1, 92d Cong., 1st Sess. (1971).

184 Possible models for a guaranteed annual income administered by the Internal Revenue Service are reviewed in C. GReEN, Negative Incone Taxes aNd the Poverty Problem (1967). For a complete survey of proposals for welfare reform, see Hearings on Income Maintenance Programs Before the Joint Economic Comm. of Congress, 90th Cong., 2d Sess. (1968).

185 The Family Assistance Plan calculates need on a quarterly basis but income during a four quarter period is taken into account. H.R. 1, 92d Cong., 1st Sess. § 2152(d) (1971). $A$ year is the basic accounting period used in the negative income tax proposals. See authorities cited note 184 supra. 
through a graduated tax on earnings rather than through the threat of disqualification from the program. ${ }^{188}$

Although a program with these characteristics would be preferable to the current programs, complete federalization of welfare administration is a distant prospect. The major proposals for a guaranteed annual income currently before Congress retain a significant role for the states in welfare administration. ${ }^{187}$ The Family Assistance Plan not only permits the states to administer some of the federal requirements but also assumes that many states will continue to operate welfare programs independent of the federal scheme. ${ }^{188}$ As long as state programs survive, no federal solution to the problem of welfare for strikers will be possible short of an amendment to the NLRA prohibiting welfare grants to strikers. The better course is to reform AFDC-U (and food stamps along with it) ${ }^{189}$ in the hope that such reform will be extended throughout the welfare system.

The first priority for reform is to improve welfare administration in the case of short-term unemployment among persons who earn substantial long-term incomes. A union member whose annual income greatly exceeds the poverty line may presently qualify for welfare

186 A negative income tax would include strikers because the work requirement would be eliminated in favor of a tax incentive as a means of inducing work. $I d$. The Family Assistance Plan retains a strong work requirement. H.R. 1, 92d Cong., 1st Sess. § 2111 (1971). But the bill clarifies the status of strikers by adding the following language:

(c)(1) Every individual ... shall participate in manpower services or training, and accept and continue to participate in employment in which he is able to engage, except where good cause exists .... as provided by the Secretary of Labor.

(2) No individual shall be required under section (1) to accept employment if-

(A) the position offered is vacant due directly to a strike, lockout, or other labor dispute;

(C) as a condition of being employed, the individual would be required to join a company union or to resign from or refrain from joining any bona fide labor organization.

Id. \& 2111. Similar language was contained in the version originally proposed by the Administration. H.R. 16311, 91st Cong., 2d Sess. \& 448 (1970). An Administration spokesman explained that strikers would be permitted to receive benefits under this language. Hearings on H.R. 16311 Before the Senate Comm. on Finance, 91st Cong., 2d Sess. at 323 (1970) (statement by Asst. Sec. of Labor Jerome Rosow) [hereinafter cited as Hearings]. But it was emphasized that few strikers were expected to become eligible under the administration bill because the annual income level for eligibility was low. Id. at 452-55 (statement of HEW Sec. Elliot Richardson). Amendments added by the House Ways and Means Committee in 1971 raised the income level. H.R. 1, 92d Cong., 1st Sess. § 2152(b) (1971).

187 The amount of local control retained in pending legislation is criticized in B. STEIN, supra note 105, at 109-13, 116-19, 121 (1971).

188 State freedom to grant or deny benefits to strikers extends to General Assistance programs (which survive under the proposal) and to the state portion of the federal-state matching grant under the federal program. Hearings, supra note 186, at 363.

189 All proposals, including the Family Assistance Plan, would gradually abolish the food stamp program. See, e.g., H.R. 1, 92d Cong., 1st Sess. $\& 502$ (1971). 
benefits if his income is sufficiently reduced during the strike period..$^{190}$ It is possible to reduce the number of such persons eligible for benefits without also excluding the truly needy by determining eligibility on the basis of long-term income as well as short-term need. Aid could be granted to persons who otherwise earn substantial incomes, but the recipients should be required to repay the government. Such reforms could be accomplished at the federal level by enactment of welfare measures currently before Congress and at the state level by revision of repayment provisions already in existence.

Under either the negative income tax proposal or the Family Assistance Plan, need would be calculated on the basis of yearly or quarterly income. While reducing the number of strikers currently eligible for welfare programs, these measures would not eliminate all strikers since some strikes can cause a drastic reduction in total yearly income and some strikers whose income might not decrease enough to qualify them for benefits may require access to cash during the strike. ${ }^{191}$ In the first situation a striker would receive benefits because his total income for the year or the quarter fell below the established minimum standard of subsistence. In the second situation benefits would also be granted but repayment would be required. ${ }^{102}$ The second situation arises because the use of a lengthy accounting period such as a year makes calculation of total income at any point during the period impossible. ${ }^{193}$ A person's earnings may increase sharply near the end of the year, and it is always difficult to predict the length of a strike in advance. Overpayment in some instances is, therefore, inevitable and repayment procedures are required. They could be administered either by the Internal Revenue Service ${ }^{194}$ or by the welfare program offcials. ${ }^{105}$

The current federal regulations do not specifically require the states

190 See text at notes 83-85 supra.

191 It is desireable to protect persons from a temporary interruption in income even if they would not qualify for benefits on an annual basis. Proposals for welfare reform that suggest taking a long-range view of a person's earnings potential also encourage making payments to persons on the basis of short-term income fluctuations. See, e.g., Tobin, Pechman, \& Mieszkowski, Is a Negative Income Tax Practical?, 77 Yale L.J. I (1967). The Family Assistance Plan provides for grants of aid on the basis of sudden reductions in an applicant's income even though his income for an entire three-month period might not fall below the standard of need. H.R. 1, 92d Cong., 1st Sess. § 2152(d) (1971).

192 The Administration proposal provides for repayment by the recipient in any case of overpayment. H.R. 1, 92d Cong., 1st Sess. § 2171(b) (1971).

193 The difficulties of administering a negative income tax are explored in Tobin et al., supra note 193.

$184 I d$.

195 H.R. 1, 92d Cong., 1st Sess. \& 2171(b) (1971). 
to enact repayment provisions, but they implicitly allow the states to recover relief payments by providing for federal sharing in the proceeds. ${ }^{196}$ Existing state repayment provisions are, however, rarely effective in the strike context. The eight states that presently require repayment from recipients of AFDC-U benefits ${ }^{197}$ usually enforce the obligation by placing a lien on nonhomestead property or other assets rather than by laying claim to income itself. ${ }^{198}$ Since the obligation is usually not enforced on money or property needed for the use of the recipient, repayment is often deferred until the death of the obligor or the sale of the assets. Most important, many states with lien requirements do not enforce them where welfare dependency is expected to be of short duration. ${ }^{199}$ Repayment provisions have been criticized, therefore, for placing the greatest burden on those most dependent on welfare, thus preventing them from becoming self-supporting. ${ }^{200}$

The present provisions, which are designed only to reduce the cost of welfare, should be redesigned to improve incentives to work and to recover temporary aid granted to persons who earn large annual incomes. If obligations were levied on such persons, substantial repayment would be achieved without burdening those who have the least incentive to leave the welfare rolls. Repayment would also be more efficient than at present if it were taken from the recipient's income rather than his assets. In the absence of federal welfare reform, then, the states should require that a recipient of either AFDG-U or General Assistance benefits whose income is reduced because of participation in a labor dispute or whose reemployment is imminent repay the state out of his subsequent annual income if that income remains above the welfare level.

Such improvements in welfare administration would largely resolve the problem of striker eligibility. To permit strikers with long-term needs to receive benefits without obliging them to repay would serve the purpose of the AFDC-U program to preserve family stability. The consequence for the federal labor policy would be that workers re-

19642 U.S.C. $\$ 603(\mathrm{~b})(2)(1970)$.

197 These are Connecticut, Hawaii, Illinois, Kansas, New Jersey, New York, Utah, and Tennessee. Graham, Public Assistance: The Right to Receive; the Obligation to Repay, 43 N.Y.U.L. REv. 451, 482 (1968). However, Connecticut, Kansas, and Tennessee do not grant benefits to strikers under the AFDC-U program. See statutes cited note 52 supra.

$198 \mathrm{New}$ York, for example, which has the nation's strictest repayment statute, does not place a lien on future income. N.Y. Soc. SERvicEs LAw \& 104 (McKinney 1966). For a complete analysis of such laws and their legal justification, see Graham, supra note 197, at 481-82, 489-94.

199 See text and note at note 78 supra.

200 Cf. Snell v. Wyman, 281 F. Supp. 853, 869-73 (S.D.N.Y. 1968) (Kaufman, J., dissenting). 
ceiving low wages, such as the California Farm Workers, might receive substantial benefits during a strike without the obligation to repay while workers in strong, well-paid unions would usually be required to repay any benefits they received. The free collective bargaining policy of the NLRA would thus be served by protecting laborers at the organizing stage, where they are least able to endure a long strike, and by reducing benefits to laborers whose bargaining position is better established. The problem of striker eligibility is thus reduced to the question where to set the standard of income above which strikers will be denied welfare benefits or required to repay benefits received.

In choosing a particular standard the legislature may draw a line between its interest in aiding low-income families and its interest in preserving the present framework for collective bargaining. ${ }^{201} \mathrm{~A}$ legislature or administrative agency is thus able to balance social interests in a way that was impossible for the Minter court. The court could only reach an all-or-nothing solution either by applying a preemption test or by construing such vague terms as "good cause" and "involuntary unemployment." Its willingness to defer to a legislative solution is, therefore, clearly appropriate.

Robert W. Clark III

201 Sponsors of the Administration's original Family Assistance Plan, for example, admitted that the proposal would have provided little support for strikers despite the fact that it did not exclude them from the program. Hearings, supra note 186, at 323, 363, 452-55. Amendments to the program would raise the income floor for all citizens so that presumably more strikers might be eligible. E.g., H.R. 1, 92d Cong., 1st Sess. § 2152(b) (1971). Yet even if the income floor reached the level presently in force in liberal states such as Massachusetts, Michigan, and Illinois, fewer strikers would be eligible than now because need would be calculated on a yearly rather than monthly basis. 